\title{
Artigos
}

\section{"Algo tão simples de viver e controlar, mas difícil de compartilhar e defender": HIV/Aids, segredos e socialidades em uma rede social on-line}

"Something that is so simple to experience and control, yet difficult to share and defend": HIV/Aids, secrets and sociability in an on-line social network (abstract: p. 13)

\section{"Algo tan sencillo de vivir y controlar, pero difícil de compartir y defender": $\mathrm{VIH} / \mathrm{Sida}$, secretos y socializaciones en una red social on-line (resumen: p. 14)}

\section{Éverson de Brito Damasceno ${ }^{(a)}$}

<everson.damasceno@outlook.com>

\section{Lumena Cristina de Assunção Cortez ${ }^{(\mathrm{b})}$}

<lumena@usp.br>

\section{Fábbio de Souza Ferreira(c)}

$<$ fabbiosouzaferreira@gamil.com>

Mercês de Fátima dos Santos Silva ${ }^{(d)}$

<mercês.santos30@gmail.com> (iD

Lucas Pereira de Melo(e)

<lpmelo@usp.br>
(a) Graduando do curso de Medicina, Escola Multicampi de Ciências Médicas, Universidade Federal do Rio Grande do Norte (UFRN). Avenida Coronel Martiniano, 541. Caicó, RN, Brasil. 59300-000.
(b) Pós-graduanda do Programa Interunidades de Doutoramento em Enfermagem, dos campi São Paulo e Ribeirão Preto (Doutorado), Universidade de São Paulo. Ribeirão Preto, SP, Brasil.
(c) Administrador de empresas. Ribeirão Preto, SP, Brasil.
(d) Faculdade de Ciências da Saúde do Trairi, UFRN. Santa Cruz, RN, Brasil.
(e) Departamento de Enfermagem Psiquiátrica e Ciências Humanas, Escola de Enfermagem de Ribeirão Preto, Universidade de São Paulo. Ribeirão Preto, SP, Brasil.

As recentes pesquisas socioantropológicas têm apontado o papel das redes sociais na internet na experiência de pessoas que vivem com adoecimentos de longa duração. Por 11 meses realizamos uma etnografia virtual entre pessoas que vivem com HIV/Aids (PVHA) membros de um grupo virtual secreto no Facebook. Buscamos compreender as práticas de socialidade existentes entre os membros do grupo investigado nessa rede social. Por meio da observação e da análise das postagens e comentários, evidenciamos as práticas de acolhimento e ajuda mútua entre os membros do grupo. Discutimos, ainda, o caráter seletivo dessas práticas, uma vez que eram mediadas por julgamentos morais e pudores, próprios do pânico sexual e/ou moral que marcou o início da epidemia, o que desvelou continuidades entre mundo on-line e off-line.

Palavras-chave: Síndrome de imunodeficiência adquirida. HIV. Internet. Experiência com a enfermidade. Ajuda mútua. 


\section{Introdução}

Este trabalho teve como objetivo compreender as práticas de socialidade entre pessoas que vivem com o vírus da imunodeficiência humana/síndrome da imunodeficiência adquirida (HIV/Aids) membros de um grupo virtual secreto em uma rede social na internet. Os resultados apresentados aqui foram produzidos no contexto de uma pesquisa mais ampla na qual temos nos debruçado sobre as experiências de PVHA $^{(f)}$ no Brasil. Nesse sentido, a condição de viver com o HIV/Aids é tomada como um tipo de adoecimento e sofrimento de longa duração ou doença comprida, na perspectiva antropológica. Essas nomenclaturas, suscitadas em contextos etnográficos, buscam provocar o caráter hegemônico do termo "doença crônica", cunhado pela medicina moderna, na medida em que tentam registrar e nomear "aquilo que veio para ficar" ${ }^{1}$.

Nessa perspectiva, o interesse nas práticas de socialidade entre PVHA membros de um grupo virtual secreto ${ }^{(\mathrm{g})} \mathrm{em}$ uma rede social na internet se deve ao cenário contemporâneo de restrição discursiva sobre o HIV/Aids ${ }^{2}$ no qual algumas dessas pessoas têm vivido, em uma condição de segredo/silêncio. A partir da análise desse autor, consideramos que o segredo/silêncio instaura uma contradição no viver com o HIV/Aids como uma condição de longa duração, na medida em que a restrição contemporânea dos discursos sobre a doença traz à luz dimensóes simbólicas antes narradas como "morte civil" por ativistas vinculados ao movimento social em HIV/ Aids nos anos $1980^{3}$. No contexto atual, essa "morte civil" tem se atualizado como uma "doença-segredo", implicando uma nova forma de morte simbólica:

Visto que se não mais se morre por HIV, continua-se ainda a morrer no silêncio da impossibilidade de revelação da situação sorológica das pessoas; na rejeição advinda de uma exposição pública, o que envolveria a morte dos afetos e mesmo, ainda, aspectos como vergonha, silenciamento, abandono, mesmo em se tratando da existência de tratamentos eficazes como os que há hoje². (p. 498-9)

Diante desse cenário, é possível compreender o porquê de algumas PVHA (como algumas interlocutoras deste estudo) se reunirem em redes sociais na internet, construindo, assim, espaços possíveis (embora não sejam os únicos e não impliquem na eliminação de outras formas de encontros e de socialidades) para reunião e interação, uma vez que nesses espaços podem ter contato com outras PVHA, com garantias de sigilo e anonimato ${ }^{(\mathrm{h})}$, e fora dos contextos face a face nos quais essas pessoas estão inseridas. Além disso, a construção desses espaços virtuais produzidos e mediados online tem relação com o uso crescente da internet no Brasil.

Em 2016, 64,7\% dos brasileiros com dez anos de idade ou mais utilizaram a internet. Desses, $85 \%$ eram jovens com idade entre 18 e 24 anos. No que tange à finalidade do acesso, $94,2 \%$ a utilizaram para enviar ou receber mensagens de texto, voz ou imagem por aplicativos diferentes de e-mail ${ }^{4}$. Em 2014, a empresa comScore ${ }^{5}$ divulgou que 90,8\% dos brasileiros acessavam redes sociais na internet, sendo o Facebook a mais acessada (94\%) e na qual se passava a maior parte do tempo conectado (96,7\%). Tratase, portanto, de uma sociedade que tende, cada vez mais, a se aproximar daquilo que Bauman e Mauro ${ }^{6}$ denominaram de "sociedade hiperconectada". Nesse sentido, esses espaços virtuais ou ciberespaços necessitam ser compreendidos como um continuum on-line e off-line, e não como duas realidades que se excluem mutuamente (real versus virtual), de maneira que precisamos evitar reificar esses espaços e as relaçóes que neles (f) Utilizamos o termo PVHA, em detrimento de PVHIV como recomendado pelo Programa Conjunto das Nações Unidades sobre HIV/aids (Unaids), para sermos coerentes com os posicionamentos e os usos dos nossos interlocutores.

(g) De acordo com a rede social, quanto à privacidade, um grupo pode ser classificado como público, fechado ou secreto. Cada tipo de grupo tem regras específicas sobre quem poderá entrar no grupo e o que as pessoas podem visualizar.

\footnotetext{
(h) Embora a literatura aponte o anonimato como uma prerrogativa desses espaços virtuais, no grupo investigado esse aspecto não se evidenciava, uma vez que, para participar do grupo, era necessário utilizar o perfil pessoal no Facebook.
} 
se desenvolvem ${ }^{7,8}$. Sendo assim, o desafio é analisar os fluxos interacionais que, mesmo acontecendo on-line, estão diretamente imbricados com a realidade objetiva desses sujeitos e com seus pertencimentos sociais de gênero, classe social, raça, sexualidade, geração, etc.

Nesse contexto, ao considerarmos que as experiências de PVHA são frequentemente acompanhadas de estigmas, segredos, discriminaçóes e isolamento social ${ }^{9-11}$, com impactos diretos em suas relações cotidianas - o que inclui as relaçóes com os serviços de saúde e seus agentes de cura -, este estudo se justifica por suas contribuições teóricas, metodológicas e políticas. Teóricas, pois dialoga e adensa o conjunto de pesquisas antropológicas sobre HIV/Aids, na medida em que desvela dimensóes da experiência de PVHA em suas incursões nas redes sociais e tensiona o discurso oficial sobre a cronicidade da infecção. Metodológicas, porque aporta aspectos e desafios do fazer etnográfico em redes sociais na internet. Por fim, políticas, ao trazer à tona pessoas, socialidades, ações, lugares e moralidades do mundo on-line e off-line que, por se localizarem às margens da política e das práticas sanitárias oficiais, modelam a experiência com "algo tão simples de viver e controlar, mas difícil de compartilhar e defender", como escreveu um de nossos interlocutores.

\section{A experiência etnográfıca no grupo virtual}

Os resultados apresentados neste artigo foram produzidos em uma etnografia conduzida entre abril de 2017 e março de 2018 (a pesquisa continua em andamento) em um grupo virtual secreto na rede social Facebook. Este grupo é uma das principais iniciativas de uma rede que reúne PVHA e pessoas que convivem com o HIV/Aids, criada em 2012.

A Rede é um grupo virtual secreto no Facebook que tem o objetivo de acolher, orientar, fortalecer e ajudar mutuamente pessoas que vivem e convivem com HIV e aids. Nesse espaço, formado por soropositivos e soronegativos que convivem/trabalham com quem vive com o HIV, os membros podem obter informaçôes sobre a vida após o diagnóstico positivo, fazer amizade, compartilhar suas dúvidas, medos, experiências, vitórias, conquistas e histórias. Dentro desse espaço, os membros poderão encontrar outras pessoas que vivem situaçóes parecidas e podem encontrar ajuda através das experiências ${ }^{(i)}$.

Conhecemos o grupo por meio da fala de Luana ${ }^{(\mathrm{j})}$, uma ativista que vivia com HIV/ Aids, em um evento alusivo ao Dia Mundial de Luta contra a Aids, em dezembro de 2016, em Caicó-RN, Brasil. Em sua narrativa, Luana sublinhava que o grupo reunia muitas PVHA que mantinham suas sorologias positivas para o HIV em segredo ${ }^{(\mathrm{k})}$, além de pessoas que conviviam com este, de várias regióes do Brasil e mesmo estrangeiros. Durante o coffee break, apresentamo-nos à Luana e perguntamos mais sobre o grupo, bem como o que fazer para participar. Além de nos dizer os "caminhos das pedras", ela exclamou para um dos pesquisadores que também é PVHA: “entra lá que você vai gostar!” Em fevereiro de 2017, esse pesquisador ingressou no grupo, o que, posteriormente, possibilitou o desenvolvimento do trabalho de campo. (i) Todas as informações sobre a Rede foram retiradas de sua página na internet, porém, por questões éticas, manteremos o anonimato da organização [citado 26 Ago 2018].

(j) Utilizamos nomes fictícios para garantir o anonimato dos nossos interlocutores. Esta pesquisa seguiu as recomendações éticas contidas na Resolução no 510/2016, do Conselho Nacional de Saúde, e foi aprovada pelo Comitê de Ética em Pesquisa da Faculdade de Ciências da Saúde do Trairi, Universidade Federal do Rio Grande do Norte, sob o ${ }^{0}$ 1.947.922/2017. Todos os interlocutores assinaram o Termo de Consentimento Livre e Esclarecido.

${ }^{(k)}$ A dimensão do segredo era diversificada e se referia, principalmente, às relações dos membros com familiares, parceiros afetivo-sexuais (casuais ou duradouros), amigos, vizinhos, colegas de trabalho e de escola/ faculdade. Nesse sentido, para alguns, apenas os profissionais de saúde sabiam; para outros, algumas pessoas das relações descritas anteriormente; poucos, entretanto, não viviam com a condição em segredo. 
O acesso ao grupo era realizado mediante preenchimento de um formulário com dados pessoais e perguntas sobre motivação e condição sorológica disponibilizado na página da Rede. Outra forma de acesso era a indicação feita por algum membro do grupo, porém, o ingresso só era efetivado após avaliação dos moderadores. O primeiro pesquisador que ingressou no grupo teve acesso por meio do preenchimento do formulário. Feito isso, foi solicitada autorização aos administradores do grupo para realização da pesquisa. Estes, após darem a anuência, fizeram uma postagem fixa ${ }^{(l)}$ na página do grupo sobre a pesquisa, seus objetivos, os procedimentos de coleta de dados, as questóes éticas e os pesquisadores envolvidos. Em seguida, mais um pesquisador foi incluído no grupo utilizando seu perfil pessoal no Facebook.

Dessa forma, essa etnografia se desenvolveu a partir daquilo que Peirano ${ }^{12}$ chamou de "instinto etnográfico" na medida em que nos alertou "para o fato de que muitas vezes a vida repete a teoria” (p. 378) e, nessa perspectiva, a etnografia não se resume a um método, "mas [é] uma forma de ver e ouvir, uma maneira de interpretar, uma perspectiva analítica, a própria teoria em ação.” ${ }^{13}$ (p. 3). Dentro desse quadro teóricometodológico, trabalhamos, especificamente, com a etnografia virtual, uma vez que o trabalho de campo se deu por meio do estudo dos fluxos de interaçóes que se davam em um grupo virtual secreto composto por PVHA e pessoas que conviviam com o HIV/ Aids no Facebook. Nesse sentido, o que se analisou foram os sentidos e as práticas de socialidade que ali eram produzidas. Com isso, não se buscou reificar o mundo on-line; pelo contrário, o foco estava também em como se imbricavam, nas interaçôes mediadas e produzidas no grupo, aspectos do mundo off-line em um movimento de "mão dupla" ${ }^{\prime, 14}$.

Sendo assim, o trabalho de campo e a análise dos dados se deram nos marcos da corrente teórica da Antropologia da Saúde brasileira que privilegia a noção antropológica de pessoa, em detrimento da noção de indivíduo indiferenciado, universal e abstrato, tão comum nos saberes, nas práticas e nas políticas de saúde ${ }^{15}$. Com isso, buscamos considerar os aspectos simbólicos, afetivos e relacionais e as complexas interações entre sujeito-sociedade-cultura na experiência da doença ${ }^{16}$. Nesse sentido, o foco da investigação se voltou à descrição dens $a^{17}$ orientada por uma perspectiva integrada, relacional e holística, que se contrapôs àquela fisicalista $\mathrm{e}$ cientificista própria da biomedicina ${ }^{15}$. Além disso, os dados etnográficos suscitaram discussóes com os estudos já consagrados na literatura socioantropológica sobre HIV/ Aids, internet, redes e mídias sociais e seus reflexos no campo da saúde.

Durante o trabalho de campo, o grupo contava com mais de 2.900 integrantes brasileiros e estrangeiros que moravam em diferentes regióes do Brasil ou viviam em outros países. Havia uma orientação, dada pelos administradores, que estimulava os ingressantes no grupo a fazerem uma breve descrição sobre si: "copie e cole no seu perfil pra gente te conhecer melhor: Nome? Apelido? Idade? Signo? Aniversário? Comidas preferidas? Raça/cor? Acredita num Deus? Ciumento? Vive com HIV? Há quanto tempo? Indetectável? Gosta de animais? Tem filhos? Cidade? Relacionamento?”. Em geral, as pessoas que respondiam a essas questóes incluíam uma fotografia pessoal. Pouco tempo após entrarmos no grupo, fizemos também a nossa apresentação, pois, em julho de 2017, muitos membros do grupo o fizeram. Essas postagens produziram um ambiente de socialização importante, pois permitiam aos membros conhecerem outras pessoas e identificarem aquelas que estavam na mesma cidade ou muito (l) Esse tipo de postagem fica fixada no início da página, não tendo sua localização alterada pelo fluxo de postagens, o que facilita sua leitura por todos durante o tempo que estiver disponível. 
próximas. Além disso, as pessoas costumavam curtir e comentar as postagens, o que resultava em descontração e, às vezes, algumas paqueras.

Esses momentos foram de grande importância, pois conseguimos ter uma noção dos pertencimentos sociais dos membros. A maioria tinha entre vinte e quarenta anos de idade; era homens (cisgêneros e homossexuais); o tempo de diagnóstico oscilou entre dias e mais de vinte anos, com carga viral indetectável; vivia, em geral, em capitais e regióes metropolitanas; autodeclarava-se negra (principalmente pardos); e era solteira. Esses aspectos foram importantes para conhecermos os membros mais ativos nas postagens e comentários durante nossas incursóes em campo que aconteciam semanalmente, com uma periodicidade média de quatro vezes por semana. Além disso, a página do grupo tem a opção de "Seguir o grupo", o que nos permitiu acompanhar as novas postagens em nossos perfis pessoais no Facebook.

Nesses primeiros meses em campo, optamos por realizar uma observação offline, ou seja, mantivemo-nos anônimos em nossos acessos, sem interagir on-line com os demais membros $^{(\mathrm{m})}$. A esse anonimato dá-se o nome de lurking e a observação silenciosa é denominada lurker ${ }^{18}$. Essa estratégia também foi utilizada por Martins ${ }^{14}$ no início da sua etnografia nas comunidades "Profiles de Gente Morta” (ou PGM) e "Velórios Virtuais" no Facebook e no Orkut. As postagens (textos, fotos e vídeos), comentários e discussões realizadas pelos participantes do grupo foram arquivadas em arquivo de texto, contendo impressóes e notas dos pesquisadores; texto das postagens na íntegra; data de publicação; e comentários. Para esse registro, também foram feitos print screens da tela quando não se podia fazer download ou copiar os conteúdos das postagens. Além disso, foram produzidos diários de campo. O corpus incluiu 282 publicações e 565 comentários.

A análise do corpus se deu por meio das seguintes etapas: leitura exploratória de todo o material; leitura seletiva, de acordo com as questóes e objetivo do estudo; leitura analítica, identificando as ideias-chave do texto, ordenando-as e finalmente sintetizando-as; e leitura interpretativa, estabelecendo relações entre o conteúdo das postagens, as questóes de pesquisa e o referencial teórico, o que significou conferir um alcance mais amplo aos resultados obtidos com a leitura analítica ${ }^{19}$. Feito isso, os principais conceitos e códigos foram mapeados e reunidos em categorias por meio da técnica de codificação temática ${ }^{20}$. Desse processo, obtivemos duas categorias: (1) "Bemvindo ao grupo, honey!”: um retrato descritivo sobre o grupo virtual secreto; e (2) "Nossa vida é essa": virtualidade, socialidade e ajuda mútua. O conteúdo êmico de cada uma delas é mostrado a seguir.

\section{“Bem-vindo ao grupo, honey!": um retrato descritivo sobre o grupo virtual secreto}

Nesta categoria apresentamos uma descrição de alguns aspectos do funcionamento do grupo, enfatizando seu caráter virtual e secreto no Facebook, em que os membros se relacionavam mais abertamente quanto à exposição de suas identidades e sorologias. Além disso, enfatizamos as interaçóes sociais entre os participantes e os temas mais discutidos no período estudado.

\author{
(m) O pesquisador que também \\ é PVHA interagia de forma \\ diferente do investigador \\ soronegativo, pois costumava \\ se engajar em postagens \\ feitas por outros membros \\ concernentes a questões sobre \\ o viver com HIV/aids.
}


O grupo virtual secreto teve origem com o engajamento de seu fundador como PVHA, ativista e profissional de comunicação social que atua em ações de prevenção e comunicação em saúde. Além do grupo, a Rede é composta por:

Site com informaçóes gerais e personalizadas sobre o HIV e aids, além de histórias dos membros do grupo. O conteúdo do site foi gerado pelos membros do grupo e adaptados para uma linguagem simples e adequada à maioria das pessoas; Página [no Facebook] é onde os interessados poderão encontrar as últimas novidades e notícias sobre o mundo do HIV e, também, fazer perguntas, comentários e solicitar o convite para a entrada no grupo secreto; Grupo virtual secreto onde os membros podem compartilhar seus posts apenas com os outros membros, garantindo assim o sigilo, mas permitindo que outras pessoas que vivem e convivem com o HIV possam comentar e praticar a ajuda mútua ${ }^{(\mathrm{n})}$.

Ademais, a Rede mantém um grupo na rede social WhatsApp e conta com colaboradores (nem todos são PVHA) que também mantêm páginas e canais em redes e mídias sociais. Apesar da existência de moderadores (seis, no total) no grupo virtual secreto, seus papéis se concentravam na observância das regras de uso do grupo ${ }^{(o)}$, que preconizavam os seguintes valores e ações: colaboração, acolhimento, fortalecimento, ajuda mútua, privacidade, liberdade de falar sobre o viver/conviver com o HIV e o respeito. Outrossim, uma das regras de uso proibia "a defesa e compartilhamento de qualquer tratamento anti-HIV alternativo que indique a descontinuidade (parada) do tratamento com antirretrovirais". Caso algum membro descumprisse as regras, os outros podiam notificar os moderadores, o que poderia levar à exclusão do grupo.

Lutamos todos contra o HIV, e não uns contra os outros. Portanto, caso veja algo que não lhe agrada e esteja em desacordo com as regras do grupo, contatenos imediatamente. (Moderador, 24 nov. 17)

Além dos procedimentos para ingresso no grupo virtual secreto descritos acima, os moderadores salientavam a importância de utilizar o perfil pessoal do Facebook. "Não aceitamos perfis comerciais, fakes [falsos] ou sem fotos de perfil. Os membros que enviam convites aos amigos e conhecidos têm parcial controle e responsabilidade." (Moderador, 24 nov. 17). Essa orientação foi inclusive requerida de nós, pesquisadores, de maneira que não nos foi permitido utilizar perfis criados exclusivamente para pesquisa, como relatado em outros estudos ${ }^{7,14}$. Tratava-se de uma medida de proteção e segurança das identidades dos participantes. No entanto, apesar dessas medidas, alguns membros expressavam insegurança e temor quanto à possibilidade da existência de pessoas infiltradas: "Esse 'filtro' dos administradores não anda bom. O grupo não pode se tornar um lugar a mais para curiosos simplesmente buscarem nossa sorologia." (Flávio, 23 fev. 18). Isso os colocava em uma situação de ambiguidade, espreita e vigilância constante para que sua sorologia não "vazasse" dos limites do grupo virtual, tido como seguro. Sendo assim, diferentemente do que foi observado em outros estudos que trabalharam na perspectiva do anonimato em grupos virtuais que reuniam pessoas que viviam com condições de saúde estigmatizantes ${ }^{10,21,22}$, no grupo da Rede, a identidade sorológica podia ser virtualmente partilhada e "aliviada". (n) Todas as informações sobre a Rede foram retiradas de sua página na internet, porém, por questões éticas, manteremos o anonimato da organização [citado 26 Ago 2018].

(o) Em geral, eles intervinham em situações de conflitos e discussões (as "tretas") entre membros, em comunicados que visavam reiterar as regras de convivência no grupo, em postagens administrativas ou de recepção/convite de novos membros e na divulgação de ações dos colaboradores da Rede em outras redes e mídias sociais. 
Nesse contexto, notamos que o caráter virtual e secreto do grupo permitia uma maior aproximação entre seus membros. Sendo assim, para aqueles que mantinham o status sorológico em segredo, existia a possibilidade de compartilhar suas dificuldades abertamente e, em geral, receber suporte informacional, social e emocional. $\mathrm{Na}$ experiência de Wendel, o grupo permitia que fossem partilhadas on-line suas necessidades, dúvidas e emoções invisibilizadas pelo silêncio: "estou sempre lendo aqui o apoio que vocês postam, e isso me ajudou muito na aceitação da sorologia e a perceber que continuo o mesmo. Que posso continuar persistindo e merecer tudo que sonho, pois um vírus não vai diminuir aquilo que luto.” (1º jan. 18) Porém, nem sempre esse suporte ocorria de forma a satisfazer as necessidades do participante, pois era modelado por moralidades que envolviam visóes sobre o HIV/Aids próprias do "pânico sexual e/ou moral [no qual] converge entre si doença, sexualidade e estilos de vida"23 (p. 27); e alguns marcadores sociais de diferenças, o que retratava o continuum on-line e off-line evidenciado por Beleli ${ }^{7}$.

Essa situação ficou mais evidente quando Renata, uma travesti recém-diagnosticada com HIV, fez duas postagens no mesmo dia, em junho de 2017, com textos cheios de erros ortográficos (o que dificultava sua compreensão) e com fotos pessoais cujo contexto deixava nítida sua condição de classe social e identidade de gênero. Ela reclamava das "perguntas bobas" feitas por outros participantes que, segundo ela, "dormiam e acordavam falando de HIV/Aids". Em seu ponto de vista, havia ingressado no grupo buscando apoio, dado o sofrimento ocasionado pelo impacto do diagnóstico, pelas dificuldades de acesso ao serviço de saúde e pela necessidade de manter segredo sobre a sorologia. Essa situação fez com que Renata mudasse de cidade para que sua família não ficasse sabendo. Suas postagens, sobretudo a primeira, foram respondidas com comentários sarcásticos, cheios de risadas e expressóes que zombavam não só das reclamaçóes de Renata, mas, principalmente, da qualidade gramatical de seu texto.

Essas moralidades também foram encontradas na etnografia realizada por Beleli ${ }^{7}$ entre mulheres da classe média paulistana que usavam, notadamente, o Tinder para busca de parcerias afetivas e sexuais. Nessas buscas, suas interlocutoras mapeavam, à primeira vista, a "afinidade" com o outro por meio da análise do contexto das fotos dos perfis. Dessa maneira, a autora afirmou que "decoração da casa, formas de se vestir, adornos" sugeriam uma autoclassificação que as afastavam de homens "pobres e vulgares", agindo, portanto, como "um filtro para ver o Outro e imaginar a si mesma” (p. 104-5). Rier ${ }^{11}$ sublinhou a necessidade de relativizar a imagem amplamente difundida de que grupos de suporte on-line para PVHA são espaços seguros, uma vez que, nos sete sites investigados por ele, os dilemas do viver com o HIV/Aids foram, em geral, problematizados a partir de julgamentos morais e pudores.

Em nossa etnografia, a postagem de Renata expôs o caráter seletivo do acolhimento e da ajuda mútua anunciados e celebrados no grupo, trazendo para o mundo on-line elementos de distinção social das relaçôes no mundo off-line. Apesar disso, era comum que alguns integrantes se dispusessem a dar apoio aos recém-chegados: "Se precisar de uma amiga para conversar ou até mesmo dividir o que tão pouco sei, estou aqui! Pode me chamar no bate-papo." (Fernanda, 12 dez. 17). Esse "cuidado virtualizado" entre "novatos" e "veteranos" também foi observado nas interaçôes entre PVHA em um blog brasileiro ${ }^{10}$. 
Esses atributos do grupo se expressavam, também, na quantidade de publicaçôes feitas diariamente, especialmente em datas comemorativas, quando muitos participantes desejavam felicitaçóes; compartilhavam histórias e descobertas; mensagens de superação; e reflexões religiosas. Com frequência, as discussões apresentavam centralidade na adesão terapêutica, nos tipos de medicações, nos efeitos colaterais e na permuta de esquemas de terapia antirretroviral (Tarv), conforme afirmou Amanda: "Jujuba pra sempre meu amor! Se não o vírus volta mais forte e te leva” (3 dez. 17). Achados semelhantes foram encontrados na etnografia de Picelli e Díaz-Bermúdez ${ }^{24}$ em grupos de ajuda mútua no Distrito Federal, Brasil. Em uma outra etnografia virtual realizada com jovens soropositivos que frequentavam salas de bate-papo da UOL e/ou participavam de grupos do Facebook, o tema da medicação também foi frequente, tendo em vista que os interlocutores buscavam estratégias para combinar os medicamentos de forma a produzirem menos efeitos colaterais e, consequentemente, minimizar seus impactos na vida cotidiana ${ }^{25}$.

Além desses temas, os membros costumavam abordar o monitoramento das "taxas" (carga viral e CD4, principalmente) e de atividade física, alimentação, sono, controle do estresse, preocupações com o surgimento de novos sintomas ou de uma infecção oportunista e problemas na dispensação das medicações no Sistema Único de Saúde (SUS). Esses últimos problemas eram temas nas postagens e comentários cotidianos, sobretudo quando faltava ou havia racionamento de medicamentos nos serviços do SUS - algo recorrente desde 2016, o que, em última instância, desvela o processo contínuo de desmonte da resposta política brasileira à epidemia.

Desde os anos 1990, a resposta brasileira à epidemia foi reconhecida nacional e internacionalmente pela formulação de políticas públicas intersetoriais, pela interlocução entre Estado e movimentos sociais, pela oferta de tratamento universal pelo SUS e, consequentemente, pela cronificação da infecção. Porém, na última década, ativistas e pesquisadores têm denunciado as fragilidades políticas do discurso que anuncia o "fim da aids" 26 , notadamente no contexto brasileiro, diante do aumento das taxas de incidência tanto da infecção pelo HIV quanto da aids; do subfinanciamento do SUS; dos entraves colocados pela propriedade intelectual ao acesso à Tarv de qualidade; das dificuldades financeiras e jurídicas das organizaçôes da sociedade civil que trabalham com prevenção e educação em HIV/Aids; e do recrudescimento da moral conservadora no país e seus impactos nas discussões de gênero, sexualidade e direitos humanos na formulação de políticas e na produção legislativa ${ }^{27-29}$.

Por outro lado, no grupo também havia publicaçôes que discutiam sobre as experiências do viver com e apesar do HIV/Aids, o que incluía: segredo e revelação da sorologia; relações familiares; medo da rejeição e abandono social; implicações nas dinâmicas afetivo-sexuais após o diagnóstico; situações de preconceito e discriminação; e o enfrentamento do estigma diante da condição. Depois de um tempo de diagnóstico, alguns membros costumavam localizar as vicissitudes da vida cotidiana com o HIV/ Aids mais no espaço público do que no privado, pois se tratava, segundo Maurício, de "algo tão simples de viver e controlar, mas difícil de compartilhar e defender" (28 nov. 17). 
Nesta categoria destacamos de que forma o contexto de socialidade, de partilha de saberes e de suporte on-line se colocava diante da invisibilidade, do segredo e do silêncio sobre a sorologia. Com base nisso, também problematizamos o perfilpadrão de usuário aceito no grupo, relacionando com seu modo de gerenciamento da condição sorológica, com o protagonismo político-social, além da busca e manutenção de relacionamentos afetivo-sexuais.

Conforme discutimos na categoria anterior, as interaçôes no grupo virtual secreto da Rede, produzidas e mediadas pela internet, construíam-se com base no compartilhamento de uma condição clínica em comum: a sorologia positiva para o HIV. Nesse sentido, tratava-se de um espaço no qual essas pessoas podiam se engajar em processos de formação de "identidades clínicas", como denominado por Valle ${ }^{30}$, uma vez que estavam relacionadas à experiência de saúde e doença. Ainda segundo o autor, essas identidades clínicas dizem respeito "à construção particular de categorias, imagens, representaçôes culturais e discursos sobre a soropositividade, que têm sido produzidos por meio de uma combinação de forças sociais e culturais de origens e formaçôes amplamente diferenciadas.” (p. 191). Assim como na etnografia de Valle ${ }^{30}$ no Grupo Pela Vidda, na capital fluminense, a socialidade no grupo virtual secreto da Rede foi fundamental na construção e reconhecimento dessa identidade clínica.

Dessa forma, as socialidades engendradas no grupo produziam essa identidade clínica, juntamente com a adesão a um regime terapêutico específico. Aqui precisamos acentuar a vinculação indireta do grupo ao discurso oficial do Ministério da Saúde. A socialidade no grupo era orientada por suas regras de uso, dentre as quais destacamos:

É absolutamente proibida a defesa e compartilhamento de qualquer tratamento anti-HIV alternativo que indique a descontinuidade (parada) do tratamento com antirretrovirais, porém relatos de dificuldade ou não adesão são permitidos. Terapias complementares são bem-vindas, desde que associada ao tratamento convencional indicado pela equipe de saúde e que esteja nos protocolos de tratamento do Ministério da Saúde(p).

Nesse sentido, o acolhimento e a ajuda mútua deviam se dar em um campo de saberes, de práticas e de experiências balizado pela política de saúde de inspiração biomédica e epidemiológica. Como consequência, o corpo se colocava como lugar da moral, instaurando sobre os sujeitos um exercício constante de autovigilância e autocontrole em busca da saúde ${ }^{31}$, no qual a adesão à Tarv e o consequente status indetectável da carga viral eram o principal alvo, como comentou Paulo: "Sempre fui religioso com a medicação. Ela é, com certeza, nossa amiga!” (3 dez. 17).

Somava-se a isso o contexto de difusão de biotecnologias, o que implicava no desenvolvimento de "ações pedagógicas" em saúde cujo objetivo era formar "sujeitosmodelos", "exemplos"32 que, nesse caso, enquadravam-se no perfil-padrão mais aceito e bem recebido no grupo investigado: um indivíduo autodisciplinado, que aderia ao tratamento, permanecia “indetectável”, discutia de maneira "leve" e multiplicava o discurso da prevenção. Como consequência, notava-se uma secundarização das dificuldades com o tratamento e das incertezas de sua condição, em detrimento do foco na Tarv e no controle do vírus, como vimos nas postagens de Renata e, também, na de Maria: "Aqui é só um querendo ser melhor que o outro, como se indetectável (p) Todas as informações sobre a Rede foram retiradas de sua página na internet, porém, por questões éticas, manteremos o anonimato da organização [citado 26 Ago 2018]. 
fosse competência para uma vida saudável” (12 dez. 17). Fábio também questionou o enfoque dado à carga viral indetectável quando respondeu às questôes para apresentação dos membros, como comentado anteriormente: "Indetectável? Essa pergunta é pra criar uma casta?” (14 jul. 2017).

Ser indetectável, como um novo atributo da identidade clínica entre PVHA, vem ganhando novos sentidos e fomentando novas práticas de socialidade, a partir da afirmação, pelo Ministério da Saúde e por sociedades científicas, de que a pessoa com carga viral indetectável não transmite o HIV (indetectável = intransmissível). Essa constatação baseada em evidências científicas já vinha sendo empregada por PVHA em situação de revelação da sorologia, por exemplo, em relaçóes afetivo-sexuais ${ }^{10}$. $\mathrm{Na}$ experiência dos membros do grupo investigado, ser "indetectável” podia, por um lado, encorajar a revelação da sorologia positiva, embora, por outro, ressaltar a "sigilosa" e "sufocante" realidade enfrentada por muitos que viviam em segredo. Aqui se inscreve a contradição apontada por Inácio ${ }^{2}$, uma vez que essas pessoas não compartilhavam sua condição, principalmente por medo de enfrentar os preconceitos dos outros, como salientou Álvaro: "Quando você sente na pele o peso da ignorância e do preconceito, você guarda o segredo e precisa sufocar a dor. A faca entra na sua carne, mas você tem que continuar sorrindo" (29 jan. 18).

Outrossim, nesses espaços virtuais de suporte para PVHA que se constroem em contextos de restrição discursiva e invisibilidade do HIV/Aids, pouco se problematiza a revelação do status sorológico, o que pode acentuar a necessidade de viver a condição na dimensão íntima e privada de cada um, como discutido por Rier ${ }^{11}$. Essa questão também foi observada neste estudo, embora tenha havido algumas situações que contrastavam com essa realidade. "Esse ano assumi a sorologia publicamente em meu aniversário, pois percebi que o processo de desconstrução do estigma do HIV/ Aids passa pela aceitação de nossa condição sorológica. Hoje, 1 de dezembro, data simbólica, compartilhei uma postagem aberta no Facebook para somar forças." (Pedro, $1^{\circ}$ dez. 17).

Além disso, observamos inúmeras iniciativas de organização de encontros off-line entre membros do grupo que moravam na mesma cidade ou região, principalmente em finais de semana e feriados. Esses encontros ocorriam em parques públicos, bares, casas ou apartamentos. No fim dos encontros off-line, essas pessoas costumavam postar fotos no grupo, nas quais apareciam sorridentes e felizes por poderem se socializar sem a necessidade de esconder sua sorologia. Em abril de 2017, por exemplo, foram postadas fotos de um encontro em São Paulo entre dez rapazes, todos membros do grupo. Os comentários da postagem ressaltavam a importância desses encontros: "semana que vem podia rolar em Brasília” (João, 23 abr. 17); e "MASSA!!! Nunca deixem de se apoiar, fortalecer e seguir adiante na luta por QUALIDADE de vida!!” (Júnior, 23 abr. 17).

Cumpre destacar ainda a postagem sobre membros do grupo hospitalizados em decorrência da infecção pelo HIV/Aids ou, mais raramente, daqueles que faleceram. Nesses momentos, os comentários que se seguiam denunciavam as incertezas sobre o futuro e o quanto a condição de indetectável poderia ser fugaz. Lembramos, por exemplo, da postagem feita em um sábado pela manhã que comunicava o falecimento, por aids, de um rapaz de aproximadamente trinta anos de idade. Tratavam-se, portanto, de situações nas quais se ratificavam a importância da solidariedade, da ajuda mútua e 
da luta cotidiana para viver com e apesar do HIV/Aids, sendo o grupo um espaço no qual era possível experimentar essas partilhas.

\section{Considerações finais}

Esta pesquisa buscou compreender as práticas de socialidade entre PVHA membros de um grupo virtual secreto em uma rede social na internet. A partir do trabalho de campo etnográfico, o estudo permitiu apreender as principais características do grupo, de seus integrantes, os temas mais discutidos e, principalmente, os contextos de socialidade que integravam pessoas, açóes, lugares e moralidades do mundo on-line e off-line. Nesse sentido, o trecho de uma postagem que dá nome a esse artigo sintetiza as relaçóes de partilha, apoio, esclarecimento e luta diante das dificuldades de viver com o HIV/Aids em contextos de restrição discursiva sobre essa condição e de expansão do uso de redes sociais na internet.

Além disso, os resultados aqui apresentados possibilitaram compreender o caráter seletivo do acolhimento e da ajuda mútua que figura no objetivo do grupo, uma vez que essas práticas de socialidade são mediadas por julgamentos morais e pudor, próprios do pânico sexual e/ou moral que marcou o início da epidemia. Ademais, tal seletividade se inscreve em classificaçóes sociais que distinguem alguns membros e suas pautas a partir de eixos de diferenciação e hierarquização. Contudo, a utilização

\section{Contribuições dos autores}

Éverson de Brito Damasceno realizou o trabalho de campo, participou da discussão dos resultados, da redação do manuscrito e aprovou a versão final do manuscrito. Lumena Cristina de Assunção Cortez, Fábbio de Souza Ferreira e Mercês de Fátima dos Santos Silva participaram da discussão dos resultados e da redação do manuscrito; e aprovaram sua versão final. Lucas Pereira de Melo concebeu e delineou o trabalho, realizou o trabalho de campo, participou da discussão dos resultados, realizou revisão crítica do conteúdo e aprovou a versão final do manuscrito.

\section{Agradecimentos}

Esta pesquisa passou a contar, em 2018, com os seguintes financiamentos: Processo no 2018/07846-6, Fundação de Amparo à Pesquisa do Estado de São Paulo (Fapesp); e Processo no 430361/2018-1, Conselho Nacional de Desenvolvimento Científico e Tecnológico (CNPq). Além disso, agrademos as bolsas de Iniciação Científica (CNPq 2017-2018) e de Mestrado pela Coordenação de Aperfeiçoamento de Pessoal de Nível Superior (Capes).

\section{Direitos autorais}

Este artigo está licenciado sob a Licença Internacional Creative Commons 4.0, tipo BY (https://creativecommons.org/licenses/by/4.0/deed.pt_BR). 
da observação off-line pode ter se colocado como uma limitação deste estudo, uma vez que não houve uma interlocução direta (por meio de entrevistas, por exemplo) com os membros do grupo. Ademais, este estudo permitiu destacar a necessidade de novas investigaçóes que, a despeito dos ganhos da cronificação da infecção, abordem os usos sociais e políticos do caráter de longa duração do HIV/Aids, com ênfase na invisibilidade das PVHA e no desmonte gradual e sistemático da resposta política brasileira à epidemia.

\section{Referências}

1. Fleischer S, Franch M. Uma dor que não passa: aportes teórico-metodológicos de uma antropologia das doenças compridas. Polit Trab. 2015; 42:13-28.

2. Inácio EC. Carga zerada: HIV/Aids, discurso, desgaste, cultura. Via Atl. 2016; 29:479505.

3. Daniel H. Vida antes da morte. 2a ed. Rio de Janeiro: Associação Brasileira Interdisciplinar de AIDS; 1994.

4. Instituto Brasileiro de Geografia e Estatística. Acesso à internet e à televisão e posse de telefone móvel celular para uso pessoal: 2016. Rio de Janeiro: IBGE; 2018.

5. Banks A, Yuki T. O cenário das redes sociais e métricas que realmente importam [Internet]. Comscore; 2014 [citado 17 Ago 2018]. Disponível em: https://www. comscore.com

6. Bauman Z, Mauro E. Babel: entre a incerteza e a esperança. Rio de Janeiro: Zahar; 2016.

7. Beleli I. O imperativo das imagens: construção de afinidades nas mídias digitais. Cad Pagu. 2015; 44:91-114.

8. Miller D, Slater D. Etnografia on e off-line: cibercafés em Trinidad. Horiz Antropol. 2004; 10(21):41-65.

9. Maksud I. Silêncios e segredos: aspectos (não falados) da conjugalidade face à sorodiscordância para o HIV/Aids. Cad Saude Publica. 2012; 28(6):1196-204.

10. Borges REA, Silva MFS, Melo LP. "Mas não tive coragem de contar”: a revelação da condição sorológica na experiência amorosa de pessoas que vivem com HIV. Saude Soc. 2017; 26(3):664-75.

11. Rier DA. Internet social support groups as moral agents: the ethical dynamics of HIV+ status disclosure. Sociol Health Illn. 2007; 29(7):1043-58.

12. Peirano M. Etnografia não é método. Horiz Antropol. 2014; 20(42):377-91.

13. Peirano M. Etnografia, ou a teoria vivida. Porto Urbe. 2008; 2:1-11.

14. Martins A. Netnografia: etnografia no mundo virtual. Rev Bras Sociol Emoçôes. 2013; 12 Supl 1:19-27.

15. Duarte LFD. Indivíduo e pessoa na experiência da saúde e da doença. Cienc Saude Colet. 2003; 8(1):173-83.

16. Aureliano WA. Trajetórias terapêuticas familiares: doenças raras hereditárias como sofrimento de longa duração. Cienc Saude Colet. 2018; 23(2):369-80. 
17. Geertz C. The interpretation of cultures. New York: Basic Books; 1973.

18. Hine C. Etnografía virtual. Barcelona: Editorial UOC; 2004.

19. Gil AC. Métodos e técnicas em pesquisa social. 5a ed. São Paulo: Atlas; 1999.

20. Flick U. An introduction to qualitative research. 4 a ed. London: Sage; 2009.

21. Separavich MA, Canesqui AM. Análise das narrativas sobre a menopausa de um site brasileiro da internet. Interface (Botucatu). 2012; 16(42):609-22.

22. Garbin HBR, Guilam MCR, Pereira Neto A. Internet na promoção da saúde: um instrumento para o desenvolvimento de habilidades pessoais e sociais. Physis. 2012; 22(1):347-63.

23. Valle CG. Mediadores e experts biossociais: saúde, ativismo e criminalização da infecção do HIV. In: Teixeira CC, Valle CG, Neves RC, organizadores. Saúde, mediação e mediadores. Brasília: ABA Publicações, Natal: EDUFRN; 2017. p. 26-75.

24. Picelli I, Díaz-Bermúdez XP. Será que esse remédio vai valer a pena mesmo? Estudo antropológico sobre a adesão às terapias antirretrovirais entre grupos de mútua ajuda de pessoas vivendo com HIV/Aids. Saude Soc. 2014; 23(2):496-509.

25. Silva LAV, Duarte FM, Alves Netto GR. Sociabilidades “positivas” em rede: narrativas de jovens em torno do HIV/Aids e suas tensóes cotidianas. Physis. 2017; 27(2):335-55.

26. Kenworthy N, Thomann M, Parker R. From a global crisis to the 'end of AIDS': new epidemics of signification. Glob Public Health. 2018; 13(8):960-71.

27. Brasil. Ministério da Saúde. Boletim epidemiológico: HIV e AIDS. Brasília: Ministério da Saúde; 2017.

28. Kerr L, Kendall C, Guimarães MDC, Mota RS, Veras MA, Dourado I, et al. HIV prevalence among men who have sex with men in Brazil: results of the 2 nd national survey using respondent-driven sampling. Medicine. 2018; 97(1S):9-15.

29. Basthi A, Parker R, Terto Jr V. Mito vs realidade: sobre a resposta brasileira à epidemia de HIV e AIDS em 2016. Rio de Janeiro: Associação Brasileira Interdisciplinar de AIDS; 2016.

30. Valle CG. Identidades, doença e organização social: um estudo das "pessoas vivendo com HIV e aids”. Horiz Antropol. 2002; 8(17):179-210.

31. Ortega F. Práticas de ascese corporal e constituição de bioidentidades. Cad Saude Colet. 2003; 11(1):59-77.

32. Cunha C. Os muitos reveses de uma "sexualidade soropositiva": o caso dos jovens vivendo com HIV/Aids. Sex Salud Soc. 2012; 10:70-99. 
Recent research in the field of social anthropology has highlighted the influence of social media on the experiences of people living with long-term illnesses. A virtual ethnography involving people living with HIV/Aids (PLHIV) who are members of a secret Facebook group was conducted over a period of 11 months. The study aimed to gain an insight into the social practices adopted by PLHIV through the observation and analysis of posts and comments. The results show that the members foster a welcoming attitude and mutual help. We also discuss the selective nature of these practices, which are measured by moral judgments and shame arising from the sexual and/or moral panic that marked the beginnings of the epidemic, unveiling continuities between the online and offline worlds.

Keywords: Acquired immunodeficiency syndrome. HIV. Internet. Experience with illness. Mutual help.

Las recientes investigaciones socio-antropológicas han señalado el papel de las redes sociales en internet en la experiencia de personas que viven con enfermedades de larga duración. Durante 11 meses realizamos una etnografía virtual entre personas que viven con VIH/Sida (PVHA), miembros de un grupo virtual secreto en Facebook. En este trabajo tratamos de comprender las prácticas de socialización entre las PVHA miembros de un grupo secreto en una red social en internet. Por medio de la observación y del análisis de las publicaciones y comentarios colocamos en evidencia las prácticas de acogida y ayuda mutua entre los miembros del grupo. También discutimos el carácter selectivo de esas prácticas, puesto que eran mediadas por juicios morales y pudores, propios del pánico sexual y/o moral que marcó el inicio de la epidemia, lo que desveló continuidades entre el mundo on-line y off-line.

Palabras clave: Síndrome de inmunodeficiencia adquirida. VIH. Internet. Experiencia con la enfermedad. Ayuda mutua. 